\title{
Insights into Ecological Effects of Invasive Plants on Soil Nitrogen Cycles
}

\author{
Congyan Wang1* ${ }^{*}$, Hongguang Xiao', Jun Liu1 ${ }^{1}$, Lei Wang1, Daolin Du1,2* \\ ${ }^{1}$ Institute of Environment and Ecology, School of the Environment and Safety Engineering, Jiangsu University, \\ Zhenjiang, China \\ ${ }^{2}$ Key Laboratory of Modern Agricultural Equipment and Technology, Ministry of Education and Jiangsu Province, \\ Jiangsu University, Zhenjiang, China \\ Email: "liuyuexue623@163.com,
}

Received 28 November 2014; revised 11 December 2014; accepted 21 December 2014

Copyright (C) 2015 by authors and Scientific Research Publishing Inc.

This work is licensed under the Creative Commons Attribution International License (CC BY).

http://creativecommons.org/licenses/by/4.0/

(c) () Open Access

\section{Abstract}

The increasing degree of plant invasion is an expanding problem that affects the functioning and composition of forest ecosystems with increasing anthropogenic activities, particularly soil nitrogen (N) cycles. Numerous studies have revealed that one of the main factors for successful plant invasion is that plants could pose significant effects on soil $\mathrm{N}$ cycles via direct and/or indirect ways, such as changes in soil microbial communities, litter decomposition rates, and/or soil physicochemical properties. We thereby summarize the ecological effects of invasive plants on soil $\mathrm{N}$ cycles, including the aforementioned changes, to understand the mechanism of successful invasion. We also discuss the needs for further research on the relationship between invasive plants and soil $\mathbf{N}$ cycles.

\section{Keywords}

Invasiveness, Invasive Plants, Litter Decomposition, Soil N Cycles, Soil Microbial Community

\section{Introduction}

The rapid development of anthropogenic activities in recent years has triggered unprecedented global environmental changes, such as biological invasion mediated by invasive plants. Such plants are colonizer species carried far from their natural areas and then introduced into a new habitat with unprecedented rates, where they often establish prosperous populations outside their native distributional ranges and significantly change the properties of native ecosystems [1] [2]. These invasive plants have received an increasing concern from ecologists

\footnotetext{
Corresponding authors.
} 
because they could pose a ubiquitous threat to ecosystems worldwide [1] [3] [4], including natural habitat degradation, biodiversity decline [1] [4], and changes in the quality and quantity of forest litter input to soil ecosystem [1], forest litter decomposition rates [1] [5]-[7], community structure and metabolic activities of soil microorganisms [8]-[10], soil physicochemical properties [1] [8] [11], and soil nutrient cycles [1] [5] [9] [12]. In addition, the invasion incurs high economic damage and management challenges [13]. Thus, the ecological and economic costs induced by invasive plants across the globe have stimulated considerable interest in the mechanisms of successful plant invasion, especially the core question that why some plants are more invasive than others [14]. In particular, N cycles play an important role in successful plant invasion [4] [15].

Resource is one of the most important environmental factors for any plant species [16]. Because $\mathrm{N}$ is often the most limited nutrient element for plant growth [17]-[19], invasive plants could acquire a competitive superiority on native species when those invaders obtain substantial resources, especially $\mathrm{N}$. Therefore, $\mathrm{N}$ is crucial for successful plant invasion.

The main concern of this study is to describe the ecological effects of invasive plants on soil $\mathrm{N}$ cycles to insights into the mechanism of successful plant invasion.

\section{Importance of $\mathbf{N}$ for Invasive Plants}

Previous studies have observed N-limited condition for the biomass production of plants in many ecosystems globally [17]-[19]. $\mathrm{N}$ is a key factor determining the outcome of interspecific competition in many ecosystems [4] [5] [19]. Given that resource is one of the most important environmental factors for any plant species [16], no plant in all habitats could achieve maximization in growth, reproduction, and competitive [3] [20] [21]. However, invasive plants grow by using resources efficiently. Thus, the efficiency of $\mathrm{N}$ use or acquisition of invasive plants could maximize their invasiveness, especially in N-limited ecosystems [19] [22] [23]. Invasive plants could enhance their efficiency of $\mathrm{N}$ use or acquisition via many ways, such as photosynthetic tissue allocation, photosynthetic $\mathrm{N}$ use efficiency, $\mathrm{N}$ fixation, $\mathrm{N}$ leaching losses, gross $\mathrm{N}$ mineralization, and/or plant $\mathrm{N}$ residence time [3] [5] [19]. Thus, increased substrate availability for $\mathrm{N}$ could allow invasive plants to gain a competitive advantage over native plants.

Plant-plant interactions may play an important role in regulating the composition of communities and ecosystems [13] [24]. Not only do they control the composition of plant communities but they also have effects that spread throughout ecosystems [24]. However, external drivers (both natural and anthropogenic), such as nutrient availability, could pose an effect on plant-plant interactions [24]. Substantial evidence has revealed that plantplant interactions are an important ingredient of the mechanism by which environmental change drivers affect plants and communities, e.g., competition is commonly considered as one of the processes that determine the response of plant communities to environmental change drivers, such as plant invasion [13] [24]. Fluctuating resource availability theory suggests that a community with enhanced available resources is vulnerable to plant invasion [25]. Environmental constraint hypothesis also indicates that limited resources could restrict plant invasion, and the restriction could alleviate when the nutrient level increased [26]. A number of studies have found that invasive plants tend to have fast growth rates and respond opportunistically to nutrient (especially $\mathrm{N}$ ) through high phenotypic plasticity, which could explain why high-resource environments are likely to be invaded by such plants [4] [20] [27] [28]. Thus, the nitrophilous characteristic of invasive plants could make their preferred investment in N uptake and utilization [28]. Previous studies have observed that both native and invasive plants could acquire $\mathrm{N}$ with exogenous $\mathrm{N}$ addition in several lab/field studies, however, invasive plants grew more than native plants under the condition with exogenous $\mathrm{N}$ addition [15] [28] [29]. Increased $\mathrm{N}$ availability could thus confer a competitive advantage to fast-growing invasive plants. The results of previous studies indicated a positive relationship between the invasion degrees of invasive plants and the levels of soil nutrient (especially N) [30] [31]. A number of fertilization experiments across a wide variety of ecosystems have also revealed that increased soil $\mathrm{N}$ leads to an increase in invasive biomass and a decrease in the biomass of native plants, i.e., high $\mathrm{N}$ levels positively affect the growth and competitive advantages of invaders over natives because invaders display higher resource acquisition, lower nutrient requirements, and less resource-limited growth than natives [26] [32] [33]. High N availability favors invasive plants, and low N availability favors native plants [19]. Other studies have indicated that invasive plants may outperform natives in both low- and highresource environments [3] [34]. On the contrary, other studies have found no effect of nutrient enrichment or elevated soil $\mathrm{N}$ levels on invasion success [35]. He et al. [36] found that the competitive advantage of invasive plants remained unchanged along $\mathrm{N}$ level gradient. 
The conventional wisdom is that plants are only able to acquire soil nutrients, such as $\mathrm{N}$, from soil solution after microbial mineralization from organic (e.g., amino acids, proteins, chitins, and urea) to mineral forms (i.e., ammonium and nitrate) [29]. However, this conventional view has been revised to include direct plant access to organic N pools, particularly in infertile ecosystems [29] [37]. Although some scholars have found no evidence of plant $\mathrm{N}$ preferences [15] [29], invasive plants may be better competitors for soil $\mathrm{N}$ than native plants, and organic $\mathrm{N}$ may be less beneficial to native plants than inorganic $\mathrm{N}$ [15]. Thus, invasive plants positively affect their relative dominance over native plants in organic N soils compared with inorganic-N soils [15]. The asymmetry of the competition results may confer a competitive advantage to invasive plants over native plants [22] and create a situation through changes in the limiting availability of another resource (e.g., P, water, and/or light) indirectly [18] [38].

In sum, $\mathrm{N}$ availability may have important contributions to successful plant invasion. Thus, invasive plants could maximize their invasiveness via accelerating soil nutrient cycles, especially N cycles [9] [39]-[41].

\section{Effects of Invasive Plants on Soil N Cycles}

$\mathrm{N}$ cycle is one of the most significant nutrient cycles in terrestrial ecosystem [42]. Plants affect $\mathrm{N}$ pools and fluxes in ecosystems through increased ecosystem $\mathrm{N}$ inputs via $\mathrm{N}$ fixation, reduced ecosystem $\mathrm{N}$ losses from $\mathrm{N}$ leaching, increased soil $\mathrm{N}$ turnover via changes in gross $\mathrm{N}$ mineralization, and/or reduced plant $\mathrm{N}$ turnover via increased plant $\mathrm{N}$ residence time [4] [19] [27]. The alterations to nutrient cycles mediated by the invasion of invasive plants are divided into two categories, namely, dramatic and gradual [43]. Dramatic alterations could happen when invasive plants present a new functional trait into the ecosystem, making resources available from new sources (e.g., the introduction of $\mathrm{N}_{2}$-fixing plants into ecosystems with no such symbioses); gradual alterations happen when invasive plants possess some functional traits (e.g., size, growth rate, and/or tissue quality) that differ quantitatively from those of native plants, which could induce a high rate of nutrient uptake or turnover (e.g., the cycles involving plant-available nutrients, soil nutrients, plant nutrients, and litter-plant-available nutrients in soil) [43].

A large number of studies have shown that the alterations mediated by invasive plants on soil $\mathrm{N}$ cycles are inconsistent. These inconsistent results may be ascribed to the difference in plant types, soil physicochemical properties, and/or the time scale of the studies. For example, some investigators have found positive effects of invasive plants on soil $\mathrm{N}$ cycles, e.g., Vitousek et al. [44] found that the mean $\mathrm{N}$ input into the forest ecosystem in Hawaii caused by Myrica faya was $18 \mathrm{~kg} \mathrm{~N} \mathrm{ha}^{-1} \cdot \mathrm{year}^{-1}$, whereas other $\mathrm{N}$ inputs were only $5.5 \mathrm{~kg} \mathrm{~N} \mathrm{ha}^{-1} \cdot \mathrm{year}^{-1}$. This vanward study has become the classical example of a dramatic alteration of the nutrient cycles induced by invasive plant species. Several subsequent studies have revealed the similar results [1] [5] [41] [42]. Castro-Díez et al. [12] found that plant invasions increased $\mathrm{N}$ pools and accelerated $\mathrm{N}$ fluxes even when excluding $\mathrm{N}$-fixing invaders using a meta-analysis of 100 papers, covering 113 invasive plant species with 345 cases of invasion across the globe and reporting impacts on $\mathrm{N}$ cycle-related metrics.

Other studies have found negative effects of invasive plants on soil N cycles, e.g., Wolf et al. [45] found low soil N levels in Rocky Mountain National Park grasslands associated with invasive plants (Melilotus officinalis and $M$. alba). The low $\mathrm{N}$ availability found in the invaded patches may be mainly attributed to plant's aggressive growth pattern, long growing season, low $\mathrm{N}$ availability, and/or low $\mathrm{N}$ use efficiency [45] [46]. The ability to provide its own $\mathrm{N}$ may allow invasive plants to drive soil nutrient levels down because of their rapid consumption and growth [45]. Evans et al. [46] found that the concentration of soil inorganic $\mathrm{N}$ and the rates of soil net mineralization were reduced by 50\% after Bromus tectorum invasion into a semi-arid native perennial grassland in Utah. González-Muñoz et al. [47] also found the similar results for plant invasion on soil N cycles. The inhibited soil $\mathrm{N}$ cycles may be due to the bereaved competitive advantage of invasive plants mediated by $\mathrm{P}$ limitation on $\mathrm{N}$ fixation because $\mathrm{N}$ fixation requires high availability of $\mathrm{P}$, which constrains the success of these organisms in low-nutrient ecosystems [48].

Kourtev et al. [49] found that the invasion of Berberis thunbergii leads to an increase in soil inorganic N, whereas that of Microstegium vimineum leads to a reduction in soil inorganic N. On the contrary, invasive grasses (Avena barbata and Bromus hordeaceous) positively affect soil ammonium concentration but negatively affect soil nitrate concentration [39]. Therefore, the effects of invasive plants on soil N cycles vary per species.

Other scholars have even found neutral effects of invasive plants on soil N cycles. For example, Windham and Ehrenfeld [50] observed that although N concentration of invasive plant (Phragmites australis) litter was 
higher than that of native plant (Spartina patens) litter, the mineralization rates of $P$. australis were greater than those of $S$. patens. Thus, the compensation of increased $\mathrm{N}$ demand with increased N supply results in a neutral effect of $P$. australis invasion on the net $\mathrm{N}$ budget (input-output) in coastal marshes of the eastern United States. Herr-Turoff [51] found no differences in the total $\mathrm{N}$ or $\mathrm{NO}_{3}-\mathrm{N}$ in soils or in the concentrations of $\mathrm{NH}_{4}-\mathrm{N}$ or $\mathrm{NO}_{3}-\mathrm{N}$ released in the discharged water from wet prairie mesocosms with and without the invasion of Phalaris arundinacea. Castro-Díez et al. [52] and Scharfy et al. [53] also found neutral effects of invasive plant invasion on soil $\mathrm{N}$ or $\mathrm{P}$.

Changed soil $\mathrm{N}$ cycles are generally mediated by invasive plants through three main ways, i.e., the changed soil microbial communities, litter decomposition rates, and soil physicochemical properties.

\subsection{Changed Soil N Cycles Mediated by Invasive Plants via Changed Soil Microbial Communities}

Accumulating evidence has suggested that the main reason for successful plant invasion is that they could accelerate the succession of soil microbial communities in their rhizosphere and then strengthen microbial functions to facilitate their further invasion [19] [54] [55]. Some investigators have suggested that invasive plants could trigger changes in the structure of soil microbial communities in invaded ecosystems [54] [56] in a way that results in a positive feedback for them and a negative feedback for the native plant communities [5]. Invasive plants could benefit from the altered interactions with soil communities and by interfering with the mutualistic interactions between soil microorganisms and native plants [57]. For example, nitrate $\mathrm{N}$ and ammonium $\mathrm{N}$ are the two major $\mathrm{N}$ types of plants used directly [29]. Some scholars have affirmed that over $80 \%$ of all plant families are mycorrhizal-dependent. $\mathrm{N}$ absorption of mycorrhizal fungi is an important way to plant $\mathrm{N}$ uptake [58]. The total $\mathrm{N}$ of plant required ranged from $21 \%$ to $50 \%$, which were absorbed by their mycorrhizal symbiosis, and the proportion even reached 75\% by ectotrophic mycorrhiza [59] [60]. Mycorrhizal fungi could generally absorb and assimilate various $\mathrm{N}$ components, including inorganic $\mathrm{N}$ (e.g., nitrate and ammonium) and organic $\mathrm{N}$ (e.g., urea and amino acid) [61] [62], and mainly ammonium [61]. Inoculation tests have shown that mycorrhizal fungi could increase $\mathrm{N}$ and/or P concentrations and the growth of host plants significantly [59] [63]-[65], although some scholars have found that ectomycorrhizal fungi transfer a larger fraction of absorbed $\mathrm{N}$ to plants only under more $\mathrm{N}$ available conditions [66]. Mycorrhizal fungi could also enhance resistance to external stress (such as heavy metal pollution) and promote plant growth [63] [64] [67]. However, invasive plants are facultatively mycorrhizal fungi, which either have weak or no dependence on microscopic symbiont depending on the environment, and could gain a competitive advantage via degenerating the mycorrhizal symbiont networks on which many native plants rely [57] or receive great benefits from the associations with microscopic symbiont, reduced dependence on microscopic symbiont [54] [68], and/or alterations to the community construction of microscopic symbiont [57], and/or alterations to the community construction of microscopic symbiont [5]. This alternative dependency may be a successful strategy of some invasive plants. As an important element on the survival and competition of native plants, the absence of mycorrhizal symbiosis could alter the competitive outcome of these dominant native plants [69].

Invasive plants could create a microenvironment that facilitates its further invasion via increasing $\mathrm{N}$ availability in soil ecosystem through changed community structure and metabolic activities of soil microorganisms, which contribute to $\mathrm{N}$ cycles (i.e., N-fixing, nitrifying, nitrosifying, ammonia oxidizing, and denitrifying bacteria) [8] [39]-[41]. Moreover, invasive plants could increase $\mathrm{N}$ availability in soil ecosystem through symbiotic $\mathrm{N}_{2}$ fixation [30] [70] to gain a competitive advantage and enhance their invasiveness for further invasion. $\mathrm{N}$-fixing microorganisms, especially endophytic microorganism, could enhance the growth of symbiotic plant via increasing the levels of $\mathrm{N}$ availability and use efficiency [71]. The major source of $\mathrm{N}$ for invasive plants (Spartina alterniflora) is its rhizospheric N-fixing microorganisms [72]. Ehrenfeld [30] confirmed that the invasion of invasive plants that support symbiotic N-fixers could pose a large effect on soil $\mathrm{N}$ cycles. As a result, the increased $\mathrm{N}$ availability through $\mathrm{N}$-fixing may favor the growth, establishment, and spread of other invasive plants and facilitate their further invasion, particularly in previously $\mathrm{N}$ poor ecosystems [1].

A number of studies have indicated that invasive plants could also affect the community structure of soil microorganisms. For example, Si et al. [10] found that Wedelia trilobata invasion can trigger changes in the richness of soil fungal community but not in soil bacterial community. Lorenzo et al. [73] revealed that Acacia dealbata invasion can lead to significant increases in the richness of soil bacterial community and significant reductions in the richness of soil fungal community in grassland ecosystems. Zhao et al. [74] found that the 
function of soil microbial metabolism and soil microbial biomass $\mathrm{C}$ and $\mathrm{N}$ were enhanced, whereas soil microbial community functional diversity was reduced following the invasion of Flaveria bidentis. The changed community structure of soil microorganisms mediated by invasive plants could affect soil $\mathrm{N}$ cycle because the fungi-to-bacteria ratio has been found to be negatively correlated with net $\mathrm{N}$ mineralization rates [75].

An increase in $\mathrm{N}$ availability could mediate a priming effect on the activities of some components of soil microbial community. Priming theory suggests that positive priming effects should be most pronounced in soils characterized by low nutrient availability, especially N [76] [77]. Ammonium could cause larger priming effects on soil microbial community than nitrate [78]. As a factor contributing to the invasiveness of invasive plants, increased soil $\mathrm{N}$ could accelerate the succession of soil microorganism communities and strengthen microbial functioning to facilitate further plant invasion [13] [39] [56].

Furthermore, plant invasion may pose a legacy effect on soil microorganism communities in invaded ecosystems, which continues to give negative effects on the establishment and growth of the next generation of native plants [9] [79], through the release of alleopathic compounds, changes in resource availability, nutrient cycles, and/or accumulation of pathogens [80].

\subsection{Changed Soil N Cycles Mediated by Invasive Plants via Changed Litter Decomposition Rates}

Leaf litter decomposition, the accompanying release of nutrients and $\mathrm{CO}_{2}$, and the formation of soil organic matter are fundamental processes in ecosystem nutrient cycles, C flux, and humus formation [81] [82]. Thus, invasive plants must have higher rates of litter decomposition obtain more nutrients for their further invasion, especially N. Invasive plants could also affect soil $\mathrm{N}$ cycles via the changed rates of litter decomposition. At the community level, litter decomposition rates are controlled by plants or functional type composition [82]. Thus, plant invasion into a new ecosystem could pose a profound change in community structure and functions [83], mainly including changes in litter decomposition and nutrient cycles [40] [41]. Plants could affect litter decomposition through direct and indirect ways. Direct effects are mediated via the quality of leaf litter, whereas indirect effects are related to unique conditions that the plants created in their surrounding environment [84]. The concentration of litter $\mathrm{N}$ of invasive plants is generally often higher than that of native plants [40] [41]. As one of the important indicators of litter quality, the concentration of litter $\mathrm{N}$ is one of the main factors affecting the rates of litter decomposition, i.e., high-quality litters that contain higher concentration of $\mathrm{N}$ tend to be decomposed faster than low-quality litters that contain lower concentration of $N$ [81] [82]. Meanwhile, litter from exotics contains less lignin and lower lignin: $\mathrm{N}$ ratios than that of congeneric natives [85]. Thus, the rates of litter decomposition of invasive plants are typically higher than that of native plants [5] [40] [41] [82] [85]. The differences in litter quality are often reflected by the amounts of microdecomposers colonizing it, and fungi typically dominate microdecomposer communities on low-quality litters because of their lower nutrient requirements and metabolic activities than those of bacteria [81] [86]. However, increasing $\mathrm{N}$ could decrease the ratio of fungal and bacterial biomass [86]-[88] because this condition negatively affects the competitive ability of fungi for $\mathrm{N}$ acquisition [89]. Meanwhile, the invasion of exotic invaders could pose positive effects on soil bacterial communities and negative effects on soil fungal communities [73] that may decrease the decomposition rates of low-quality litters, which are the typical representative of native plants, according to previous results. Moreover, low-quality litters contain substantial lignin, and increasing $\mathrm{N}$ could lead to a reduction of lignin decomposition efficiency [81] [87] [90] because lignin-degrading fungi are inefficient in their C use, grow slowly, and are likely to be outcompeted by other microorganisms when $\mathrm{N}$ is abundant [90] because of the fact that a high concentration of low-molecular weight $\mathrm{N}$ compounds suppress the synthesis of lignin-degrading enzymes [87] and lead to a reduction of polyphenol decomposition efficiency by the formation of recalcitrant matters after the complexation between $\mathrm{N}$ and polyphenols [87]. Invasive plants could also create a microclimate in soil ecosystem that facilitates litter decomposition by increasing soil temperature and moisture [7] [91]. Through a meta-analysis, Liao et al. [41] found that plant invasion could accelerate the rates of litter decomposition by $116.80 \%$ in invaded ecosystems; the amplitudes of plant underground $\mathrm{N}$ pool, plant aboveground $\mathrm{N}$ pool, plant $\mathrm{N}$ concentrations, litter $\mathrm{N}$ concentrations, microbial $\mathrm{N}$ pool, soil total $\mathrm{N}$ pool, soil net nitrification rates, and soil net mineralization rates were $111.66 \%$, $85.63 \%, 40.18 \%, 37.70 \%, 25.81 \%, 19.25 \%, 53.11 \%$, and $51.80 \%$, respectively.

Diverse ranges of plant species exist in natural ecosystems after plant invasion; thus, the litter of invasive plants is often mixed with that of native plants in the invaded ecosystem, which could affect litter decomposition 
through litter mixing [82] [92]. The chemical environment and microdecomposer community may be altered when litters mixed because of species difference in resource quality and structure [82] [92]. By mixing species at different litter evenness levels, the ratios of different types of structure and nutrients may also be altered [21] [92] [93]. Evenness could thereby affect litter decomposition because of the non-linear responses of decomposition to changes in litter quality [21] [93]. High species evenness generally facilitates litter decomposition rates [93]. As leaf structure and chemical composition may vary among species, species composition of mixed leaf packs may alter the litter decomposition rates of each species individually. Their decomposition rates may thereby result from the characteristics of all (additive effects) or dominant species (key species) [94]. High-quality litters could generally promote the decomposition of low-quality litters. The synergistic effects of litter mixing are significant when litters with different qualities are mixed [21] [82] [92] [95] [96]. The effect might be mainly caused by the: 1) transfer of decomposition-enhancing nutrients from high- to low-quality litters; 2) acceleration in decomposition rates by species-specific litters; 3) facilitation by the structural complexity of diverse litters of a favorable microclimate for decomposition; 4) enhancement of the abundance, diversity, and/or activities of soil decomposers through heterogeneous resource-base and/or high biochemical diversity of root exudates [21] [82] [96]; 5) high water retention capacity by some litter types that could be beneficial to the decomposition of other litter types [97]; 6) a significantly low richness of saprotrophic fungi in the monodominant forest relative to species-rich forest [98]; 7) soil nutrient (such as N) concentration decrease with increasing plant diversity, and/or [99], and/or 8) litters with high $\mathrm{N}$ and $\mathrm{P}$ that may induce priming effects on microdecomposer community in litters with low $\mathrm{N}$ and $\mathrm{P}$ [76] [78] and facilitate fast decomposition of low-quality litters without necessarily retarding the decomposition of high-quality litters [82] [96]. Antagonistic [94], neutral [95], or stochastic [100] effects of mixing on litter decomposition have also been observed. Species amount in litter mixture seems to also play a major role in litter decomposition, e.g., considering only the significant non-additive interactions, two-species mixtures mostly shows antagonistic effects, while great species produces synergistic interactions for mass loss and nutrient releases [101]. Over two plants generally exist in natural ecosystems after plant invasion. Thus, plant invasion could trigger the acceleration of litter decomposition rates according to previous results. invasive plants with high rates of litter decomposition and high concentration of leaf $\mathrm{N}$ could be expected to release $\mathrm{N}$ into soil ecosystem with a more rapid rate than that of native plants and facilitate the further invasion of such invaders [21] [30] [40] [41] [92]. The increased soil N availability mediated by one invasive plant species may also benefit the invasion of other invasive species and lead to a secondary plant invasion, i.e., interspecific facilitation, which could increase the numbers and impacts of plant invasions ultimately [6].

However, the study of individual exceptions has shown that the litter decomposition rates of invasive plants (Juniperus virginiana) were lower than those of native plants (Andropogon gerardii) in grasslands of eastern Kansas [102]. Godoy et al. [103] found that the litter of invasive plants tended to decompose more slowly than that of its allied native plants after comparing 19 invasive-native pairs of co-familial species from Spain. Vilà et al. [1] observed that plant invasion decreased litter decomposition by $15.6 \%$ through a meta-analysis. Low rates of litter decomposition of invasive plants may be mainly attributed to their high lignin and polyphenol concentration and low C:N ratio [1] [103]. However, Witkowski [104] found that the rates of litter decomposition of invasive $\mathrm{N}$-fixation shrub (A. saligna) were higher than those of indigenous sclerophyllous shrub (Leucospermum parile). On the contrary, the rates of litter decomposition of invasive N-fixation shrub (A. cyclops) were lower than those of indigenous sclerophyllous shrub (Pterocelastrus tricuspidatus) in coastal lowlands of Cape fynbos in South Africa. A number of studies have indicated no difference in the decomposition of native and exotic leaf plants [105]. These results suggest species-effects of the litter decomposition of invasive plants.

\subsection{Changed Soil N Cycles Mediated by Invasive Plants via Changed Soil Physicochemical Properties}

Considerable evidence has indicated that plant invasion could change soil physicochemical properties [7] [42] [45] [70] [91]. For example, invasive plants (M. officinalis and $M$. alba) could trigger the reduction of soil moisture in Rocky Mountain National Park grasslands [45]. The reason may be ascribed to the rapid growth pattern and long persistence of invasive plants that could lead to fast evapotranspiration rate [45]. However, Yelenik et al. [91] showed that invasive plants (A. saligna) could increase soil moisture and temperature. Positive correlation has also been observed between soil moisture and plant invasion [7].

$\mathrm{N}$ acquired by invasive plants could induce changes in soil $\mathrm{pH}$ values, e.g., high ammonium absorption could 
result in acidification, and high nitrate absorption could trigger alkalinization [106]. Previous studies suggested that plant invasion leads to a high soil pH value [7] [107]. However, Si et al. [10] found that low degrees of $W$. trilobata invasion significantly increased soil $\mathrm{pH}$ values, whereas high degrees of invasion did not affect soil $\mathrm{pH}$ values. Hawkes et al. [39] found that invasive grasses (Avena barbata and Bromus hordeaceous) could positively affect soil ammonium concentration but negatively affect soil nitrate concentration and induce soil acidification. The results were also achieved by other investigators [8] [17] [42] [108].

The decreased soil $\mathrm{pH}$ values mediated by plant invasion could enhance P solubility in soil ecosystem [108]. High P availability could facilitate plant invasion [17] [108]. High soil P availability is often correlated with the invasion degrees of invasive plants [11]. Thus, $P$ plays an important role in successful plant invasion [45] [109].

Soil physicochemical properties, especially soil moisture, temperature, and $\mathrm{pH}$ values, are well known as a dominant factor in regulating the community structure and metabolic activities of soil microorganisms, litter decomposition rates, and soil $\mathrm{N}$ availability [81] [110]. Thus, changes in soil physicochemical properties could affect plant invasion.

\section{Conclusions}

In summary, changes in soil $\mathrm{N}$ cycles triggered by plant invasion may be a result of the changes in the physical properties of soil ecosystem caused by the introduction of invasive plants. They might also result from the changes in the patterns of plant dominance within the plant communities where they occur because the effects of a given species on ecosystem processes are modulated by its relative abundance within the community. Changes in soil $\mathrm{N}$ cycles mediated by invasive plants via direct and/or indirect ways, such as the changed of soil microbial communities, litter decomposition rates, and/or soil physicochemical properties, may play an important role during successful plant invasion (Figure 1).

Numerous studies have investigated the ecological effects of invasive plants on soil $\mathrm{N}$ cycles in recent years. However, several shortcomings remain. We offer the following key summary points:

1) Gradual succession occurs after invaders are transported from their natural habitat and progressively establish populations in invaded ecosystems. Invasive plants thereby exert different degrees of invasion in affected areas. Thus, understanding the effects of different degrees of plant invasion on soil $\mathrm{N}$ cycles is important in elucidating the mechanism underlying the success of plant invasion. However, existing studies have often ignored the invasion degrees of invading plants or did not discuss the effects of different degrees of plant invasion on soil $\mathrm{N}$ cycles.

2) Soil microorganisms can play an important role in facilitating successful plant invasion. Thus, the effects of non-native plants on the metabolic activities and community composition of soil microorganisms must be determined, especially the soil microorganisms that contribute to $\mathrm{N}$ cycling (e.g., $\mathrm{N}$-fixing, nitrifying, nitrosifying, ammonia oxidizing, and denitrifying bacteria), to understand the effects of invasive plants on soil $\mathrm{N}$ cycles and forecast the potential invasiveness in the coming years.

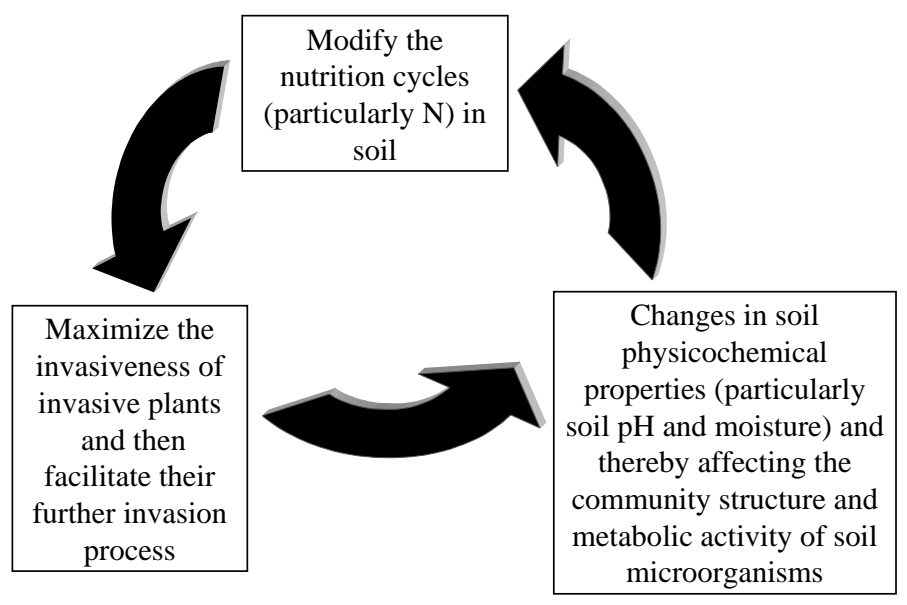

Figure 1. The diagram of the interactive feedback between invasive plants, soil properties, and soil $\mathrm{N}$ cycles. 
3) The increasing human activities in recent decades have induced global climate and environmental changes, such as elevated atmospheric $\mathrm{N}$ deposition. Human-induced climate and environmental changes, such as atmospheric $\mathrm{N}$ deposition, can affect species distribution and resource dynamics in terrestrial and aquatic ecosystems, which may exacerbate the threat of non-native plants on native ecosystems. Therefore, understanding how nonnative plants can invade ecosystems is a major challenge to ecologists, especially under the condition of global changes, in order to better understand thoroughly the ecological effects of invasive plants on native ecosystems and their potential invasion. However, information on the effects of invasive plants on soil $\mathrm{N}$ cycles under the condition mediated by atmospheric $\mathrm{N}$ deposition is limited, especially under $\mathrm{N}$ deposition, not only with gradient $\mathrm{N}$ addition but also with various $\mathrm{N}$ form addition or mixed $\mathrm{N}$ addition that contains various $\mathrm{N}$ components. Natural atmospheric $\mathrm{N}$ deposition contains various $\mathrm{N}$ components, including inorganic $\mathrm{N}$ (e.g., ammonium and nitrate) and organic $\mathrm{N}$ (e.g., urea, amino acids, aliphatic amines, peroxyacyl nitrates, $\mathrm{N}$ heterocyclic compounds, alkyl nitrates, and methyl cyanide). $\mathrm{N}$ deposition varies in its form, and changes in the form of $\mathrm{N}$ deposits are expected in future. Therefore, identifying the effects of invasive plants on $\mathrm{N}$ cycles under different forms of $\mathrm{N}$ deposition (especially organic $\mathrm{N}$ deposition or even mixed $\mathrm{N}$ deposition containing various $\mathrm{N}$ components) is an important task in understanding the successful mechanism of plant invasion under the condition with anthropogenic $\mathrm{N}$ deposition.

\section{Acknowledgements}

This study was supported by the National Natural Science Foundation of China (31300343, 31170386), Natural Science Foundation of Jiangsu Province, China (BK20130500), Universities Natural Science Research Project of Jiangsu Province, China (13KJB610002), Project Funded by the Priority Academic Program Development of Jiangsu Higher Education Institutions (PAPD), and Research Foundation for Advanced Talents, Jiangsu University (12JDG086).

\section{References}

[1] Vilà, M., Espinar, J.L., Hejda, M., Hulme, P.E., Jarošík, V., Maron, J.L., Perg, J., Schaffner, U., Sun, Y. and Pyšek, P. (2011) Ecological Impacts of Invasive Alien Plants: A Meta-Analysis of Their Effects on Species, Communities and Ecosystems. Ecology Letters, 14, 702-708. http://dx.doi.org/10.1111/j.1461-0248.2011.01628.X

[2] Powell, K.I., Chase, J.M. and Knight, T.M. (2013) Invasive Plants Have Scale-Dependent Effects on Diversity by Altering Species-Area Relationships. Science, 339, 316-318. http://dx.doi.org/10.1126/science.1226817

[3] Funk, J.L. and Vitousek, P.M. (2007) Resource-Use Efficiency and Plant Invasion in Low-Resource Systems. Nature, 446, 1079-1081. http://dx.doi.org/10.1038/nature05719

[4] Theoharides, K.A. and Dukes, J.S. (2007) Plant Invasion across Space and Time: Factors Affecting Nonindigenous Species Success during Four Stages of Invasion. New Phytologist, 176, 256-273. http://dx.doi.org/10.1111/j.1469-8137.2007.02207.x

[5] Sanon, A., Beguiristain, T., Cébron, A., Berthelin, J., Sylla, S.N. and Duponnois, R. (2012) Differences in Nutrient Availability and Mycorrhizal Infectivity in Soils Invaded by an Exotic Plant Negatively Influence the Development of Indigenous Acacia Species. Journal of Environmental Management, 95, S275-S279. http://dx.doi.org/10.1016/i.jenvman.2011.01.025

[6] Flory, S.L. and Bauer, J.T. (2014) Experimental Evidence for Indirect Facilitation among Invasive Plants. Journal of Ecology, 102, 12-18. http://dx.doi.org/10.1111/1365-2745.12186

[7] Kuebbing, S.E., Classen, A.T. and Simberloff, D. (2014) Two Co-Occurring Invasive Woody Shrubs Alter Soil Properties and Promote Subdominant Invasive Species. Journal of Applied Ecology, 51, 124-133. http://dx.doi.org/10.1111/1365-2664.12161

[8] Dassonville, N., Guillaumaud, N., Piola, F., Meerts, P. and Poly, F. (2011) Niche Construction by the Invasive Asian Knotweeds (Species Complex Fallopia): Impact on Activity, Abundance and Community Structure of Denitrifiers and Nitrifiers. Biological Invasions, 13, 1115-1133. http://dx.doi.org/10.1007/s10530-011-9954-5

[9] Elgersma, K.J., Ehrenfeld, J.G., Yu, S. and Vor, T. (2011) Legacy Effects Overwhelm the Short-Term Effects of Exotic Plant Invasion and Restoration on Soil Microbial Community Structure, Enzyme Activities, and Nitrogen Cycling. Oecologia, 167, 733-745. http://dx.doi.org/10.1007/s00442-011-2022-0

[10] Si, C.C., Liu, X.Y., Wang, C.Y., Wang, L., Dai, Z.C., Qi, S.S. and Du, D.L. (2013) Different Degrees of Plant Invasion Significantly Affect the Richness of the Soil Fungal Community. PLOS ONE, 8, e85490. http://dx.doi.org/10.1371/journal.pone.0085490 
[11] Weidenhamer, J.D. and Callaway, R.M. (2010) Direct and Indirect Effects of Invasive Plants on Soil Chemistry and Ecosystem Function. Journal of Chemical Ecology, 36, 59-69. http://dx.doi.org/10.1007/s10886-009-9735-0

[12] Castro-Díez, P., Godoy, O., Alonso, A., Gallardo, A. and Saldaña, A. (2014) What Explains Variation in the Impacts of Exotic Plant Invasions on the Nitrogen Cycle? A Meta-Analysis. Ecology Letters, 17, 1-12. http://dx.doi.org/10.1111/ele.12197

[13] Mitchell, C.E., Agrawal, A.A., Bever, J.D., Gilbert, G.S., Hufbauer, R.A., Klironomos, J.N., Maron, J.L., Morris, W.F., Parker, I.M., Power, A.G., Seabloom, E.W., Torchin, M.E. and Vazquez, D.P. (2006) Biotic Interactions and Plant Invasions. Ecology Letters, 9, 726-740. http://dx.doi.org/10.1111/j.1461-0248.2006.00908.x

[14] Schmidt, J.P. and Drake, J.M. (2011) Why Are Some Plant Genera More Invasive than Others? PLoS ONE, 6, e18654. http://dx.doi.org/10.1371/journal.pone.0018654

[15] Jones, R.O. and Chapman, S.K. (2011) The Roles of Biotic Resistance and Nitrogen Deposition in Regulating NonNative Understory Plant Diversity. Plant and Soil, 345, 257-269. http://dx.doi.org/10.1007/s11104-011-0778-y

[16] Ren, M.X. and Zhang, Q.G. (2009) The Relative Generality of Plant Invasion Mechanisms and Predicting Future Invasive Plants. Weed Research, 49, 449-460. http://dx.doi.org/10.1111/j.1365-3180.2009.00723.x

[17] Chen, B.M., Peng, S.L. and Ni, G.Y. (2009) Effects of the Invasive Plant Mikania micrantha H.B.K. on Soil Nitrogen Availability through Allelopathy in South China. Biological Invasions, 11, 1291-1299. http://dx.doi.org/10.1007/s10530-008-9336-9

[18] Hautier, Y., Niklaus, P.A. and Hector, A. (2009) Competition for Light Causes Plant Biodiversity Loss after Eutrophication. Science, 324, 636-638. http://dx.doi.org/10.1126/science.1169640

[19] Laungani, R. and Knops, J.M.H. (2009) Species-Driven Changes in Nitrogen Cycling Can Provide a Mechanism for Plant Invasions. Proceedings of the National Academy of Sciences of the United States of America, 106, 12400-12405. http://dx.doi.org/10.1073/pnas.0900921106

[20] Matzek, V. (2011) Superior Performance and Nutrient-Use Efficiency of Invasive Plants over Non-Invasive Congeners in a Resource-Limited Environment. Biological Invasions, 13, 3005-3014. http://dx.doi.org/10.1007/s10530-011-9985-y

[21] Wang, X.Y., Miao, Y., Yu, S., Chen, X.Y. and Schmid, B. (2014) Genotypic Diversity of an Invasive Plant Species Promotes Litter Decomposition and Associated Processes. Oecologia, 174, 993-1005. http://dx.doi.org/10.1007/s00442-013-2816-3

[22] Ochoa-Hueso, R., Allen, E.B., Branquinho, C., Cruz, C., Dias, T., Fenn, M.E., Manrique, E., Perez-Corona, M.E., Sheppard, L.J. and Stock, W.D. (2011) Nitrogen Deposition Effects on Mediterranean Type Ecosystems: An Ecological Assessment. Environmental Pollution, 159, 2265-2279. http://dx.doi.org/10.1016/j.envpol.2010.12.019

[23] Heberling, J.M. and Fridley, J.D. (2013) Resource-Use Strategies of Native and Invasive Plants in Eastern North American Forests. New Phytologist, 200, 523-533. http://dx.doi.org/10.1111/nph.12388

[24] Brooker, R.W. (2006) Plant-Plant Interactions and Environmental Change. New Phytologist, 171, 271-284. http://dx.doi.org/10.1111/j.1469-8137.2006.01752.x

[25] Davis, M.A., Grim, J.P. and Thompson, K. (2000) Fluctuating Resources in Plant Communities: A General Theory of Invisibility. Journal of Ecology, 88, 528-534. http://dx.doi.org/10.1046/j.1365-2745.2000.00473.x

[26] Rickey, M.A. and Anderson, R.C. (2004) Effects of Nitrogen Addition on the Invasive Grass Phragmites australis and a Native Competitor Spartina pectinata. Journal of Applied Ecology, 41, 888-896. http://dx.doi.org/10.1111/j.0021-8901.2004.00948.x

[27] Davidson, A.M., Jennions, M. and Nicotra, A.B. (2011) Do Invasive Species Show Higher Phenotypic Plasticity than Native Species and, If So, Is It Adaptive? A Meta-Analysis. Ecology Letters, 14, 419-431. http://dx.doi.org/10.1111/j.1461-0248.2011.01596.x

[28] Matzek, V. (2012) Trait Values, Not Trait Plasticity, Best Explain Invasive Species’ Performance in a Changing Environment. PLOS ONE, 7, e48821. http://dx.doi.org/10.1371/journal.pone.0048821

[29] Reynolds, H.L., Hartley, A.E., Vogelsang, K.M., Bever, J.D. and Schultz, P.A. (2005) Arbuscular Mycorrhizal Fungi Do Not Enhance Nitrogen Acquisition and Growth of Old-Field Perennials under Low Nitrogen Supply in Glasshouse Culture. New Phytologist, 167, 869-880. http://dx.doi.org/10.1111/j.1469-8137.2005.01455.x

[30] Ehrenfeld, J.G. (2003) Effects of Exotic Plant Invasions on Soil Nutrient Cycling Processes. Ecosystems, 6, 503-523. http://dx.doi.org/10.1007/s10021-002-0151-3

[31] Howard, T.G., Gurevitch, J., Hyatt, L., Carreiro, M. and Lerdau, M. (2004) Forest Invasibility in Communities in Southeastern New York. Biological Invasions, 6, 393-410. http://dx.doi.org/10.1023/B:BINV.0000041559.67560.7e

[32] Gurevitch, J., Howard, T.G., Ashton, I.W., Leger, E.A., Howe, K.M., Woo, E. and Lerdau, M. (2008) Effects of Experimental Manipulation of Light and Nutrients on Establishment of Seedlings of Native and Invasive Woody Species in 
Long Island, NY Forests. Biological Invasions, 10, 821-831. http://dx.doi.org/10.1007/s10530-008-9241-2

[33] Hebel, C.L., Smith, J.E. and Cromack Jr., K. (2009) Invasive Plant Species and Soil Microbial Response to Wildfire Burn Severity in the Cascade Range of Oregon. Applied Soil Ecology, 42, 150-159. http://dx.doi.org/10.1016/j.apsoil.2009.03.004

[34] Leishman, M.R., Thomson, V.P. and Cooke, J. (2010) Native and Exotic Invasive Plants Have Fundamentally Similar Carbon Capture Strategies. Journal of Ecology, 98, 28-42. http://dx.doi.org/10.1111/j.1365-2745.2009.01608.x

[35] Thomsen, M.A., Corbin, J.D. and D’Antonio, C.M. (2006) The Effect of Soil Nitrogen on Competition between Native and Exotic Perennial Grasses from Northern Coastal California. Plant Ecology, 186, 23-35. http://dx.doi.org/10.1007/s11258-006-9109-4

[36] He, W.M., Yu, G.L. and Sun, Z.K. (2011) Nitrogen Deposition Enhances Bromus tectorum Invasion: Biogeographic Differences in Growth and Competitive Ability between China and North America. Ecography, 34, 1059-1066. http://dx.doi.org/10.1111/j.1600-0587.2011.06835.x

[37] Leduc, S.D. and Rothstein, D.E. (2010) Plant-Available Organic and Mineral Nitrogen Shift in Dominance with Forest Stand Age. Ecology, 91, 708-720. http://dx.doi.org/10.1890/09-0140.1

[38] Blanes, M.C., Viñegla, B., Salido, M.T. and Carreira, J.A. (2013) Coupled Soil-Availability and Tree-Limitation Nutritional Shifts Induced by N Deposition: Insights from N to P Relationships in Abies pinsapo Forests. Plant and Soil, 366, 67-81. http://dx.doi.org/10.1007/s11104-012-1397-y

[39] Hawkes, C.V., Wren, I.F., Herman, D.J. and Firestone, M.K. (2005) Plant Invasion Alters Nitrogen Cycling by Modifying the Soil Nitrifying Community. Ecology Letters, 8, 976-985. http://dx.doi.org/10.1111/j.1461-0248.2005.00802.x

[40] Liao, C.Z., Luo, Y.Q., Fang, C.M., Chen, J.K. and Li, B. (2008) Litter Pool Sizes, Decomposition, and Nitrogen Dynamics in Spartina alterniflora-Invaded and Native Coastal Marshlands of the Yangtze Estuary. Oecologia, 156, 589600. http://dx.doi.org/10.1007/s00442-008-1007-0

[41] Liao, C.Z., Peng, R.H., Luo, Y.Q., Zhou, X.H., Wu, X.W., Fang, C.M., Chen, J.K. and Li, B. (2008) Altered Ecosystem Carbon and Nitrogen Cycles by Plant Invasion: A Meta Analysis. New Phytologist, 177, 706-714. http://dx.doi.org/10.1111/j.1469-8137.2007.02290.x

[42] Novoa, A., Rodríguez, R., Richardson, D. and González, L. (2014) Soil Quality: A Key Factor in Understanding Plant Invasion? The Case of Carpobrotus edulis (L.) N.E.Br. Biological Invasions, 16, 429-443. http://dx.doi.org/10.1007/s10530-013-0531-y

[43] Mack, M.C., D’Antonio, C.M. and Ley, R.E. (2001) Alteration of Ecosystem Nitrogen Dynamics by Exotic Plants: A Case of $\mathrm{C}_{4}$ Grasses in Hawaii. Ecological Applications, 11, 1323-1335.

[44] Vitousek, P.M., Walker, L.R., Whiteaker, L.D., Mueller-Dombois, D. and Matson, P.A. (1987) Biological Invasion by Myrica faya Alters Ecosystem Development in Hawaii. Science, 238, 802-804. http://dx.doi.org/10.1126/science.238.4828.802

[45] Wolf, J.J., Beatty, S.W. and Seastedt, T.R. (2004) Soil Characteristics of Rocky Mountain National Park Grasslands Invaded by Melilotus officinalis and M. alba. Journal of Biogeography, 31, 415-424. http://dx.doi.org/10.1046/j.0305-0270.2003.00983.x

[46] Evans, R., Rimer, R., Sperry, L. and Belnap, J. (2001) Exotic Plant Invasion Alters Nitrogen Dynamics in an Arid Grassland. Ecological Applications, 11, 1301-1310. http://dx.doi.org/10.1890/1051-0761(2001)011[1301:EPIAND]2.0.CO;2

[47] González-Muñoz, N., Castro-Díez, P. and Parker, I.M. (2013) Differences in Nitrogen Use Strategies between Native and Exotic Tree Species: Predicting Impacts on Invaded Ecosystems. Plant and Soil, 363, 319-329. http://dx.doi.org/10.1007/s11104-012-1329-x

[48] Finzi, A.C. and Rodgers V.L. (2009) Bottom-Up Rather than Top-Down Processes Regulate the Abundance and Activity of Nitrogen Fixing Plants in Two Connecticut Old-Field Ecosystems. Biogeochemistry, 95, 309-321. http://dx.doi.org/10.1007/s10533-009-9338-4

[49] Kourtev, P.S., Ehrenfeld, J.G. and Häggblom, M. (2003) Experimental Analysis of the Effect of Exotic and Native Plant Species on the Structure and Function of Soil Microbial Communities. Soil Biology \& Biochemistry, 35, 895-905. http://dx.doi.org/10.1016/S0038-0717(03)00120-2

[50] Windham, L. and Ehrenfeld, J.G. (2003) Net Impact of a Plant Invasion on Nitrogen-Cycling Processes within a Brackish Tidal Marsh. Ecological Applications, 13, 883-896. http://dx.doi.org/10.1890/02-5005

[51] Herr-Turoff, A. and Zedler, J.B. (2005) Does Wet Prairie Vegetation Retain More Nitrogen with or without Phalaris arundinacea Invasion? Plant and Soil, 277, 19-34. http://dx.doi.org/10.1007/s11104-004-5980-8

[52] Castro-Díez, P., González-Muñoz, N., Alonso, A., Gallardo, A. and Poorter, L. (2009) Effects of Exotic Invasive Trees 
on Nitrogen Cycling: A Case Study in Central Spain. Biological Invasions, 11, 1973-1986. http://dx.doi.org/10.1007/s10530-008-9374-3

[53] Scharfy, D., Güsewell, S., Gessner, M.O. and Venterink, H.O. (2010) Invasion of Solidago gigantea in Contrasting Experimental Plant Communities: Effects on Soil Microbes, Nutrients and Plant-Soil Feedbacks. Journal of Ecology, 98, 1379-1388. http://dx.doi.org/10.1111/j.1365-2745.2010.01722.x

[54] Kiers, E.T., Duhamel, M., Beesetty, Y., Mensah, J.A., Franken, O., Verbruggen, E., Fellbaum, C.R., Kowalchuk, G.A., Hart, M.M., Bago, A., Palmer, T.M., West, S.A., Vandenkoornhuyse, P., Jansa, J. and Bucking, H. (2011) Reciprocal Rewards Stabilize Cooperation in the Mycorrhizal Symbiosis. Science, 333, 880-882. http://dx.doi.org/10.1126/science.1208473

[55] Svensson, J.R., Nylund, G.M., Cervin, G., Toth, G.B. and Pavia, H. (2013) Novel Chemical Weapon of an Exotic Macroalga Inhibits Recruitment of Native Competitors in the Invaded Range. Journal of Ecology, 101, 140-148. http://dx.doi.org/10.1111/1365-2745.12028

[56] Wardle, D.A., Bardgett, R.D., Callaway, R.M. and van der Putten, W.H. (2011) Terrestrial Ecosystem Responses to Species Gains and Losses. Science, 332, 1273-1277. http://dx.doi.org/10.1126/science.1197479

[57] Vogelsang, K.M. and Bever, J.D. (2009) Mycorrhizal Densities Decline in Association with Nonnative Plants and Contribute to Plant Invasion. Ecology, 90, 399-407. http://dx.doi.org/10.1890/07-2144.1

[58] van der Heijden, M.G.A., Bardgett, R.D. and van Straalen, N.M. (2008) The Unseen Majority: Soil Microbes as Drivers of Plant Diversity and Productivity in Terrestrial Ecosystems. Ecology Letters, 11, 296-310. http://dx.doi.org/10.1111/j.1461-0248.2007.01139.x

[59] Govindarajulu, M., Pfeffer, P.E., Jin, H., Abubaker, J., Douds, D.D., Allen, J.W., Bücking, H., Lammers, P.J. and Shachar-Hill, Y. (2005) Nitrogen Transfer in the Arbuscular Mycorrhizal Symbiosis. Nature, 435, 819-823. http://dx.doi.org/10.1038/nature03610

[60] Paungfoo-Lonhienne, C., Lonhienne, T.G.A., Rentsch, D., Robinson, N., Christie, M., Webb, R.I., Gamage, H.K., Carroll, B.J., Schenk, P.M. and Schmidt, S. (2008) Plants Can Use Protein as a Nitrogen Source without Assistance from Other Organisms. Proceedings of the National Academy of Sciences of the United States of America, 105, 45244529. http://dx.doi.org/10.1073/pnas.0712078105

[61] Tanaka, Y. and Yano, K. (2005) Nitrogen Delivery to Maize via Mycorrhizal Hyphae Depends on the Form of N Supplied. Plant, Cell and Environment, 28, 1247-1254. http://dx.doi.org/10.1111/j.1365-3040.2005.01360.x

[62] Talbot, J.M. and Treseder, K.K. (2010) Controls over Mycorrhizal Uptake of Organic Nitrogen. Pedobiologia, 53, 169179. http://dx.doi.org/10.1016/j.pedobi.2009.12.001

[63] Chen, B.D., Xiao, X.Y., Zhu, Y.G., Smith, F.A., Xie, Z.M. and Smith, S.E. (2007) The Arbuscular Mycorrhizal Fungus Glomus mosseae Gives Contradictory Effects on Phosphorus and Arsenic Acquisition by Medicago sativa Linn. Science of the Total Environment, 379, 226-234. http://dx.doi.org/10.1016/j.scitotenv.2006.07.038

[64] Chen, B.D., Zhu, Y.G., Duan, J., Xiao, X.Y. and Smith, S.E. (2007) Effects of the Arbuscular Mycorrhizal Fungus Glomus mosseae on Growth and Metal Uptake by Four Plant Species in Copper Mine Tailings. Environmental Pollution, 147, 374-380. http://dx.doi.org/10.1016/j.envpol.2006.04.027

[65] Xie, X.Y., Weng, B.S., Cai, B.P., Dong, Y.R. and Yan, C.L. (2014) Effects of Arbuscular Mycorrhizal Inoculation and Phosphorus Supply on the Growth and Nutrient Uptake of Kandelia obovata (Sheue, Liu \& Yong) Seedlings in Autoclaved Soil. Applied Soil Ecology, 75, 162-171. http://dx.doi.org/10.1016/j.apsoil.2013.11.009

[66] Näsholm, T., Högberg, P., Franklin, O., Metcalfe, D., Keel, S.G., Campbell, C., Hurry, V., Linder, S. and Högberg, M.N. (2013) Are Ectomycorrhizal Fungi Alleviating or Aggravating Nitrogen Limitation of Tree Growth in Boreal Forests? New Phytologist, 198, 214-221. http://dx.doi.org/10.1111/nph.12139

[67] Bedini, S., Turrini, A., Rigo, C., Argese, E. and Giovannetti, M. (2010) Molecular Characterization and Glomalin Production of Arbuscular Mycorrhizal Fungi Colonizing a Heavy Metal Polluted Ash Disposal Island, Downtown Venice. Soil Biology \& Biochemistry, 42, 758-765. http://dx.doi.org/10.1016/j.soilbio.2010.01.010

[68] Harner, M.J., Mummey, D.L., Stanford, J.A. and Rillig, M.C. (2010) Arbuscular Mycorrhizal Fungi Enhance Spotted Knapweed Growth across a Riparian Chronosequence. Biological Invasions, 12, 1481-1490. http://dx.doi.org/10.1007/s10530-009-9559-4

[69] Hartnett, D.C. and Wilson, G.W.T. (2002) The Role of Mycorrhizas in Plant Community Structure and Dynamics: Lessons from the Grasslands. Plant and Soil, 244, 319-331. http://dx.doi.org/10.1023/A:1020287726382

[70] Rout, M.E. and Chrzanowski, T.H. (2009) The Invasive Sorghum halepense Harbors Endophytic $\mathrm{N}_{2}$-Fixing Bacteria and Alters Soil Biogeochemistry. Plant and Soil, 315, 163-172. http://dx.doi.org/10.1007/s11104-008-9740-z

[71] Suman, A., Shrivastava, A.K., Gaur, A., Singh, P., Singh, J. and Yadav, R.L. (2008) Nitrogen Use Efficiency of Sugarcane in Relation to Its BNF Potential and Population of Endophytic Diazotrophs at Different N Levels. Plant Growth Regulation, 54, 1-11. http://dx.doi.org/10.1007/s10725-007-9219-6 
[72] Bagwell, C.E. and Lovell, C.R. (2000) Persistence of Selected Spartina alterniflora Rhizoplane Diazotrophs Exposed to Natural and Manipulated Environmental Variability. Applied and Environmental Microbiology, 66, 4625-4633. http://dx.doi.org/10.1128/AEM.66.11.4625-4633.2000

[73] Lorenzo, P., Rodríguez-Echeverrĺa, S., González, L. and Freitas, H. (2010) Effect of Invasive Acacia dealbata Link on Soil Microorganisms as Determined by PCR-DGGE. Applied Soil Ecology, 44, 245-251. http://dx.doi.org/10.1016/j.apsoil.2010.01.001

[74] Zhao, X.H., Huangfu, C.H., Qu, B., Wang, Y.J., Wang, H., Liu, H.M. and Yang, D.L. (2014) Effects of Flaveria bidentis Invasion on Soil Microbial Functional Diversity. Journal of Agricultural Resources and Environment, 31, 182-189. (In Chinese)

[75] Smithwick, E.A.H., Naithani, K.J., Balser, T.C., Romme, W.H. and Turner, M.G. (2012) Post-Fire Spatial Patterns of Soil Nitrogen Mineralization and Microbial Abundance. PLoS ONE, 7, e50597. http://dx.doi.org/10.1371/journal.pone.0050597

[76] Craine, J.M., Morrow, C. and Fierer, N. (2007) Microbial Nitrogen Limitation Increases Decomposition. Ecology, 88, 2105-2113. http://dx.doi.org/10.1890/06-1847.1

[77] Kuzyakov, Y. (2010) Priming Effects: Interactions between Living and Dead Organic Matter. Soil Biology \& Biochemistry, 42, 1363-1371. http://dx.doi.org/10.1016/j.soilbio.2010.04.003

[78] Stout, W.L. (1995) Evaluating the Added Nitrogen Interaction Effect in Forage Grasses. Communications in Soil Science and Plant Analysis, 26, 2829-2841. http://dx.doi.org/10.1080/00103629509369491

[79] Lankau, R.A., Bauer, J.T., Anderson, M.R. and Anderson, R.C. (2014) Long-Term Legacies and Partial Recovery of Mycorrhizal Communities after Invasive Plant Removal. Biological Invasions, 16, 1979-1990. http://dx.doi.org/10.1007/s10530-014-0642-0

[80] Lankau, R.A. (2010) Soil Microbial Communities Alter Allelopathic Competition between Alliaria petiolata and a Native Species. Biological Invasions, 12, 2059-2068. http://dx.doi.org/10.1007/s10530-009-9608-Z

[81] Wang, C.Y., Han, G.M., Jia, Y., Feng, X.G., Guo, P. and Tian, X.J. (2011) Response of Litter Decomposition and Related Soil Enzyme Activities to Different Forms of Nitrogen Fertilization in a Subtropical Forest. Ecological Research, 26, 505-513. http://dx.doi.org/10.1007/s11284-011-0805-8

[82] Zhang, L., Wang, H., Zou, J.W., Rogers, W.E. and Siemann, E. (2014) Non-Native Plant Litter Enhances Soil Carbon Dioxide Emissions in an Invaded Annual Grassland. PLoS ONE, 9, e92301. http://dx.doi.org/10.1371/journal.pone.0092301

[83] Kolar, C.S. and Lodge, D.M. (2001) Progress in Invasion Biology: Predicting Invaders. Trends in Ecology \& Evolution, 16, 199-204. http://dx.doi.org/10.1016/S0169-5347(01)02101-2

[84] Vivanco, L. and Austin, A.T. (2008) Tree Species Identity Alters Forest Litter Decomposition through Long-Term Plant and Soil Interactions in Patagonia, Argentina. Journal of Ecology, 96, 727-736. http://dx.doi.org/10.1111/j.1365-2745.2008.01393.x

[85] Meisner, A., de Boer, W., Cornelissen, J.H.C. and van der Putten, W.H. (2012) Reciprocal Effects of Litter from Exotic and Congeneric Native Plant Species via Soil Nutrients. PLOS ONE, 7, e31596. http://dx.doi.org/10.1371/journal.pone.0031596

[86] Schimel, J., Balser, T.C. and Wallenstein, M. (2007) Microbial Stress-Response Physiology and Its Implications for Ecosystem Function. Ecology, 88, 1386-1394. http://dx.doi.org/10.1890/06-0219

[87] Carreiro, M.M., Sinsabaugh, R.L., Repert, D.A. and Parkhurst, D.F. (2000) Microbial Enzyme Shifts Explain Litter Decay Responses to Simulated Nitrogen Deposition. Ecology, 81, 2359-2365. http://dx.doi.org/10.1890/0012-9658(2000)081[2359:MESELD]2.0.CO;2

[88] Wei, C.Z., Yu, Q., Bai, E., Lü, X.T., Li, Q., Xia, J.Y., Kardol, P., Liang, W.J., Wang, Z.W. and Han, X.G. (2013) Nitrogen Deposition Weakens Plant-Microbe Interactions in Grassland Ecosystems. Global Change Biology, 19, 36883697. http://dx.doi.org/10.1111/gcb.12348

[89] Goddard, M.R. and Bardford, M.A. (2003) The Adaptive Response of a Natural Microbial Population to Carbon- and Nitrogen-Limitation. Ecology Letters, 6, 594-598. http://dx.doi.org/10.1046/j.1461-0248.2003.00478.x

[90] Janssens, J.A., Dieleman, W., Luyssaert, S., Subke, J.A., Reichstein, M., Ceulemans, R., Ciais, P., Dolman, A.J., Grace, J., Matteucci, G., Papale, D., Piao, S.L., Schulze, E.D., Tang, J. and Law, B.E. (2010) Reduction of Forest Soil Respiration in Response to Nitrogen Deposition. Nature Geoscience, 3, 315-322. http://dx.doi.org/10.1038/ngeo844

[91] Yelenik, S.G., Stock, W.D. and Richardson, D.M. (2004) Ecosystem Level Impacts of Invasive Acacia saligna in the South African Fynbos. Restoration Ecology, 12, 44-51. http://dx.doi.org/10.1111/j.1061-2971.2004.00289.x

[92] Chen, B.M., Peng, S.L., D’Antonio, C.M., Li, D.J. and Ren, W.T. (2013) Non-Additive Effects on Decomposition from Mixing Litter of the Invasive Mikania micrantha H.B.K. with Native Plants. PLoS ONE, 8, e66289. 
http://dx.doi.org/10.1371/journal.pone.0066289

[93] Dickson, T.L. and Wilsey, B.J. (2009) Biodiversity and Tallgrass Prairie Decomposition, the Relative Importance of Species Identity, Evenness, Richness, and Micro-Topography. Plant Ecology, 201, 639-649. http://dx.doi.org/10.1007/s11258-008-9567-y

[94] Hoorens, B., Aerts, R. and Stroetenga, M. (2003) Does Initial Litter Chemistry Explain Litter Mixture Effects on Decomposition? Oecologia, 137, 578-586. http://dx.doi.org/10.1007/s00442-003-1365-6

[95] Scherer-Lorenzen, M. (2008) Functional Diversity Affects Decomposition Processes in Experimental Grasslands. Functional Ecology, 22, 547-555. http://dx.doi.org/10.1111/j.1365-2435.2008.01389.x

[96] Chapman, S.K., Newman, G.S., Hart, S.C., Schweitzer, J.A. and Koch, G.W. (2013) Leaf Litter Mixtures Alter Microbial Community Development: Mechanisms for Non-Additive Effects in Litter Decomposition. PLoS ONE, 8, e62671. http://dx.doi.org/10.1371/journal.pone.0062671

[97] Wardle, D.A., Nilsson, M.C., Zackrisson, O. and Gallet, C. (2003) Determinants of Litter Mixing Effects in a Swedish Boreal Forest. Soil Biology and Biochemistry, 35, 827-835. http://dx.doi.org/10.1016/S0038-0717(03)00118-4

[98] McGuire, K.L., Zak, D.R., Edwards, I.P., Blackwood, C.B. and Upchurch, R. (2010) Slowed Decomposition Is Biotically Mediated in an Ectomycorrhizal, Tropical Rain Forest. Oecologia, 164, 785-795. http://dx.doi.org/10.1007/s00442-010-1686-1

[99] Scherer-Lorenzen, M., Palmborg, C., Prinz, A. and Schulze, E.D. (2003) The Role of Plant Diversity and Composition for Nitrate Leaching in Grasslands. Ecology, 84, 1539-1552. http://dx.doi.org/10.1890/0012-9658(2003)084[1539:TROPDA]2.0.CO;2

[100] Hector, A., Beale, A.J., Minns, A., Otway, S.J. and Lawton, J.H. (2000) Consequences of the Reduction of Plant Diversity for Litter Decomposition: Effects through Litter Quality and Microenvironment. Oikos, 90, 357-371. http://dx.doi.org/10.1034/j.1600-0706.2000.900217.x

[101] Bonanomi, G., Incerti, G., Antignani, V., Capodilupo, M. and Mazzoleni, S. (2010) Decomposition and Nutrient Dynamics in Mixed Litter of Mediterranean Species. Plant and Soil, 331, 481-496. http://dx.doi.org/10.1007/s11104-009-0269-6

[102] Norris, M.D., Blair, J.M. and Johnson, L.C. (2001) Land Cover Change in Eastern Kansas: Litter Dynamics of ClosedCanopy Eastern Redcedar Forests in Tallgrass Prairie. Canadian Journal of Botany-Revue Canadienne de Botanique, 79, 214-222. http://dx.doi.org/10.1139/cjb-79-2-214

[103] Godoy, O., Castro-Díez, P., van Logtestijn, R.S.P., Cornelissen, J.H.C. and Valladares, F. (2010) Leaf Litter Traits of Invasive Species Slow Down Decomposition Compared to Spanish Natives: A Broad Phylogenetic Comparison. Oecologia, 162, 781-790. http://dx.doi.org/10.1007/s00442-009-1512-9

[104] Witkowski, E.T.F. (1991) Effects of Invasive Alien Acacias on Nutrient Cycling in the Coastal Lowlands of the Cape Fynbos. Journal of Applied Ecology, 28, 1-15. http://dx.doi.org/10.2307/2404109

[105] Hata, K., Kato, H. and Kachi, N. (2012) Leaf Litter of the Invasive Casuarina equisetifolia Decomposes at the Same Rate as that of Native Woody Species on Oceanic Islands but Releases More Nitrogen. Weed Research, 52, 542-550. http://dx.doi.org/10.1111/j.1365-3180.2012.00945.x

[106] Kourtev, P.S., Ehrenfeld, J.G. and Huang, W.Z. (1998) Effects of Exotic Plant Species on Soil Properties in Hardwood Forests of New Jersey. Water, Air and Soil Pollution, 105, 493-501. http://dx.doi.org/10.1023/A:1005037105499

[107] Fan, L., Chen, Y., Yuan, J.G. and Yang, Z.Y. (2010) The Effect of Lantana camara Linn. Invasion on Soil Chemical and Microbiological Properties and Plant Biomass Accumulation in Southern China. Geoderma, 154, 370-378. http://dx.doi.org/10.1016/j.geoderma.2009.11.010

[108] Herr, C., Chapuis-Lardy, L., Dassonville, N., Vanderhoeven, S. and Meerts, P. (2007) Seasonal Effect of the Exotic Invasive Plant Solidago gigantea on Soil pH and P Fractions. Journal of Plant Nutrition and Soil Science, 170, 729738. http://dx.doi.org/10.1002/jpln.200625190

[109] Zhang, L., Zhang, Y.J., Wang, H., Zou, J.W. and Siemann, E. (2013) Chinese Tallow Trees (Triadica sebifera) from the Invasive Range Outperform Those from the Native Range with an Active Soil Community or Phosphorus Fertilization. PLOS ONE, 8, e74233. http://dx.doi.org/10.1371/journal.pone.0074233

[110] Zhang, X.M., Liu, W., Schloter, M., Zhang, G.M., Chen, Q.S., Huang, J.H., Li, L.H., Elser, J.J. and Han, X.G. (2013) Response of the Abundance of Key Soil Microbial Nitrogen-Cycling Genes to Multi-Factorial Global Changes. PLoS ONE, 8, e76500. http://dx.doi.org/10.1371/journal.pone.0076500 
Scientific Research Publishing (SCIRP) is one of the largest Open Access journal publishers. It is currently publishing more than 200 open access, online, peer-reviewed journals covering a wide range of academic disciplines. SCIRP serves the worldwide academic communities and contributes to the progress and application of science with its publication.

Other selected journals from SCIRP are listed as below. Submit your manuscript to us via either submit@scirp.org or Online Submission Portal.
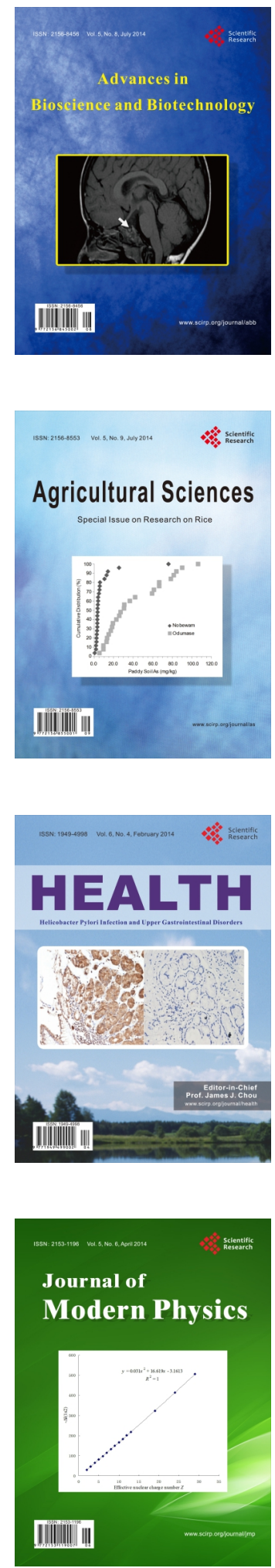
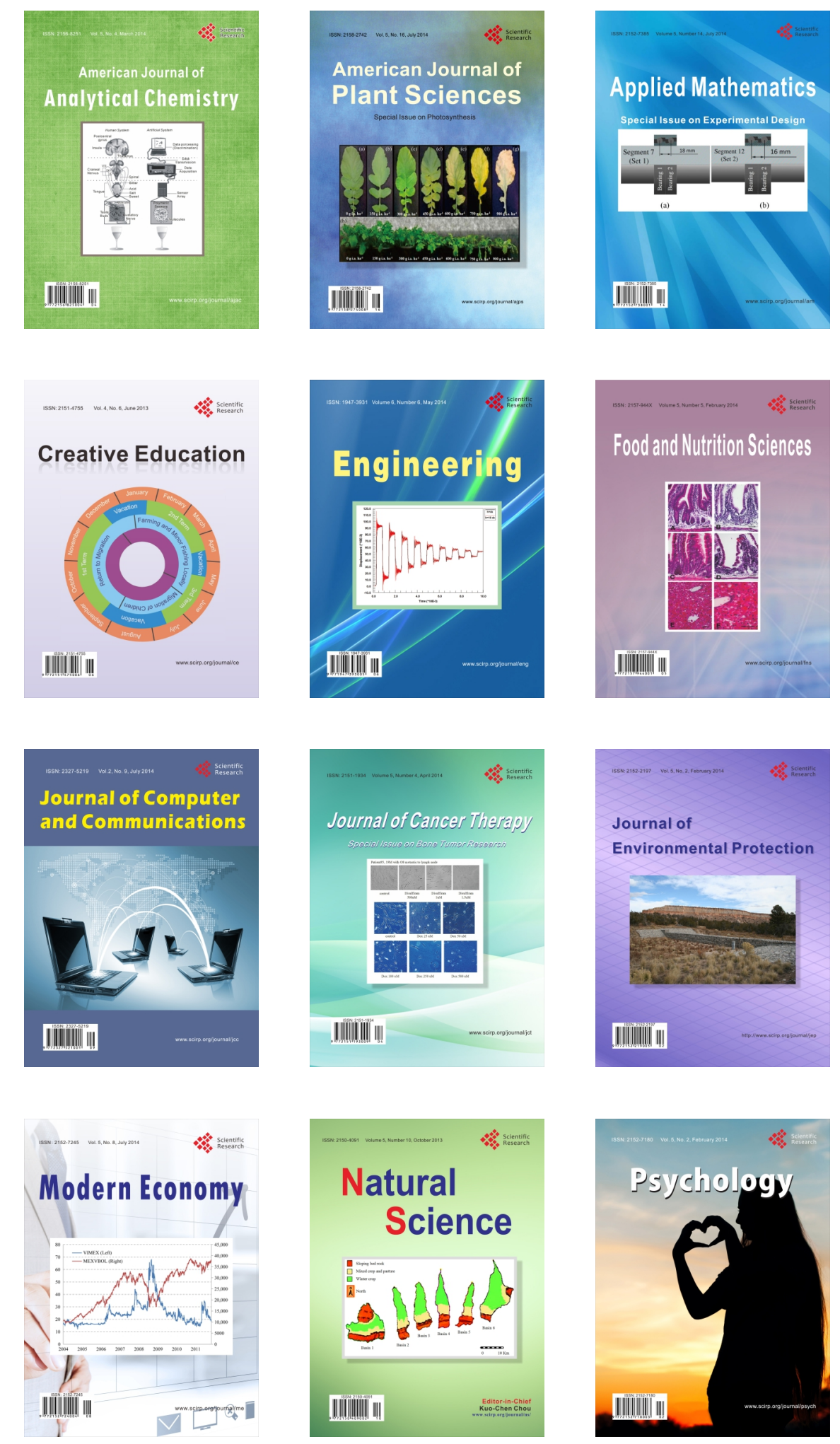